\title{
Chinese Festival Culture Teaching in Heterogeneous Culture
}

\author{
Xiuzhong Cui*
}

\author{
Shandong Foreign Trade Vocational College, China \\ *Corresponding author. Email: cxz12@163.com
}

\begin{abstract}
Through the contrast teaching of Mid-autumn festival and Slava festival in East Sarajevo University, this paper studies how to explain Chinese festival culture in the Western traditional religious culture environment. This paper expounds teaching principles and teaching enlightenment of Chinese festival culture, which has significance in spreading Chinese culture in the world. $t$ is a problem worthy of consideration and practice by international Chinese teachers that how to teach Chinese festival culture in the Western traditional religious culture environment in order to reduce students' understanding obstacles, to improve their interest in learning and understanding Chinese culture, to strengthen the consciousness of cultural acquisition in their Chinese learning and cultivation of intercultural communication ability, to improve their Chinese pragmatic competence and finally enhance the influence of Chinese culture in the world. This paper tries to do useful research and exploration based on the Mid-autumn festival teaching in East Sarajevo University.
\end{abstract} Keywords: Chinese festival culture teaching, mid-autumn festival, slava festival

\section{PRACTICE OF CHINESE FESTIVAL CULTURE TEACHING IN HETEROGENEOUS CULTURE}

There are three main nations in Bosnia and Herzegovina (BiH): Bosniaks (Muslims), Serbs, Croats, their faith in Islam, Orthodox and Catholic. Majority of Easy Sarajevo University's students is Serbs, who believe in Orthodox. The author had been worked in Department of Chinese language there. Teaching practice of Chinese festival culture in heterogeneous culture was with thirty students, who studied Lesson 28 "The Gift is Trifling but the Sentiment is Profound "of New Practical Chinese Reader Book 3.

Teaching is orderly step by step. First, students talked narrative Slava festival culture custom(The Slava festival is Serbs' very important festival.), teacher showed the Mid-autumn festival culture custom, and contrast similarities and differences between two culture custom, and cultural analysis summarized finally, using graphic teaching, multimedia teaching method etc. The teaching emphasis and difficulty is to master the spirit of the Chinese traditional culture behind the Mid-autumn festival. After students master the word and sentence patterns, guides them to understand different material culture, behavior culture and spiritual culture between the Mid-autumn festival and Slava festival.

Let students discuss Slava festival's date, subject, celebration, eating custom and spirit to be reflected (show in PPT). Then teacher explain them of the Mid-autumn festival one by one. Students find their date is different: the Mid-autumn festival is at 15 th day of the 8 th lunar month, but the date of Slava festival is not constant, each family has its own time; their subject is different: the moon is subject of the Mid-autumn festival, which is formed on the basis of priests the moon in the autumnal equinox (Chun-li Yang etc, 2007). And Slava festival is a patron Saint's day, it is alleged that the source of "Slava festival" was in early 11th century Ancient books, but some people think that the traditional had appeared from end of 9th century. The origin of Slava festival is still not completely unified today, but majority of people believe that it is evolved from the early Slavs' protocol of worshiping ancestors (Peng Zhao, 2014), the subject of Slava festival is Saints of the Bible; their celebration is different: the former is moon worshipping, moon appreciating, the whole family burned incense, the latter is Saint worshipping, with unique prayers ceremony; their eating custom is different: when the Mid-autumn festival coming, people eat moon cake, fruit, etc, And when Slava festival coming, people eat special Big Bread, Salma, Pita, drink wine, etc.

The ceremony of the Mid-autumn festival and Slava festival is very different, but people are eager to reunion and happy life. Different country, different festival, but affection and pursuit of beautiful things are the same. They are to be highlighted that Slava festival emphasis on Bible, more emphasis on the unity of God, religious sense is very thick; the Mid-autumn festival emphasis on the moon, more emphasis on the unity of nature, reflecting a farming country's culture. Chinese culture advocates harmony between the heaven and human since ancient times. Only students' mastering the concept of the Chinese traditional culture is the deep level teaching.

Due to the elaborate design teaching, the teaching effect is good, students' discuss is very warm, coupled with Chang Er flies to the moon, the Moon Rabbit, students say that 
Chinese people are very romantic, they hope to go to China for a romantic Mid-autumn festival in the future.

\section{PRINCIPLES OF CHINESE FESTIVAL CULTURE TEACHING IN HETEROGENEOUS CULTURE}

\subsection{Principle of Acculturation}

Acculturation is the core concept of acculturation theory. John Berry argues that acculturation refers to a two-way process and psychological change after cross-cultural contact. Acculturation strategy is the backbone of John Berry Theory, including assimilation, separation, and integration with marginalized (Xiao-dong Dai, 2011). The four strategies of Berry acculturation are including the two-way mode toward their own culture and the mainstream culture attitude. Not only Chinese as a second language learner exists acculturation, but also teacher exists acculturation. Chinese teachers teach Chinese in $\mathrm{BiH}$, they must adapt to culture of $\mathrm{BiH}$. With teaching Chinese traditional festival culture, teachers should follow the principle of acculturation, integrate traditional festival culture in $\mathrm{BiH}$, eliminate strangeness of student to Chinese traditional festival culture, and ease the burden on cognition, which is advantageous to the teaching process.

\subsection{Principle of Teaching Students According to Their Aptitude}

Principle of teaching students according to their aptitude is on the basis of the learners' individual differences, to choose the suitable teaching methods, to achieve the best learning effect. It includes two aspects: first, cultural elements, i.e. the teaching content should have strong pertinence; second, select the appropriate teaching task according to different teaching objects and methods. Teachers need to comparative analysis of cultural differences, so as to avoid the negative transfer of culture. Majority of Easy Sarajevo University's students believe in Orthodox. Teaching Chinese traditional festival culture, teachers should pay attention not only to the negative transfer of culture, but also to the positive transfer of culture. Only by respecting the students' own culture and introducing the content of Chinese festival culture, can we have a better learning effect.

\subsection{Principle of Step by Step}

The process of second language learning is an adaption to the target language in fact. Principle of step by step is in line with the basic law of people's understanding of things, which is a method of cultural introduction. The process of introduction is to expand the scope and depth of culture from shallow to deep, from simple to complicated, from concrete to abstract, from communicative culture to knowledge culture. In the teaching of festival culture, it is easy for students to perceive and accept the contents about the features of eating customs and the forms of festival activities, but it is more difficult to understand the contents about the cultural origin and spirit of festival.

Lack of spiritual teaching has lost its soul, so teachers must deepen step by step, layer by layer in-depth. To convey the cultural spirit behind a festival, only in this way can learners understand what kind of nation the Chinese nation is and what values it has. The Mid-autumn festival is one of Chinese traditional festivals, which embodies Chinese people's simple and kind-hearted, modest and tolerant spiritual qualities, also expresses Chinese People's yearning for a better life, and embodies Chinese People's value orientation. Through teaching, teachers should let students slowly experience the spirit of Chinese traditional culture behind the Mid-autumn festival.

\section{ENLIGHTENMENT OF CHINESE FESTIVAL CULTURE TEACHING IN HETEROGENEOUS CULTURE}

\subsection{Respect for Traditional Culture in BiH and Overcoming Cultural Centralism}

Cultural Centralism is to regard the culture to which one belongs as the center of culture, and to use it as a frame of reference and standard to evaluate other cultures (Li-dan Chen etc, 2007). Because of the different natural environment of different nationalities, the cognition, understanding and treatment of the surrounding environment are also different, so different national cultures are produced. And each culture relative to the nation is "the most reasonable existence". There is no good or bad culture; different cultures should be equal (Ling-ling Wang, 2016). Traditional festivals in both China and $\mathrm{BiH}$ have a place in the broad and profound culture, and are living fossils of inherited culture. Therefore, while teaching Chinese traditional culture festivals, international Chinese language teachers should also understand and respect the traditional culture of $\mathrm{BiH}$, not demand $\mathrm{BiH}$ culture in accordance with their own cultural values, beliefs and customs, eventually lead to a failure to understand each other's messages and intentions. This is the premise and foundation of teaching Chinese traditional festival culture in $\mathrm{BiH}$.

\subsection{Using Positive Transfer of Culture in Contrast Teaching}

When teaching Chinese traditional culture, International Chinese language teachers should be good at using the method of cultural contrast teaching, using the positive transfer of culture in contrast teaching, so that students can 
grasp Chinese culture unconsciously, and teachers should take the initiative to seek for cultural differences, it is necessary to find the commonness in culture, so as to overcome the barriers of communication between different cultures and do better cross-cultural teaching. Chinese cultural communication is a subtle, rather than hard-line indoctrination, only in this way will have twice the result with half the effort.

\subsubsection{Material culture contrast}

Because traditional festivals are deeply influenced by sacrificial rites, people prepare abundant food and fruits according to the seasons in order to express the reverence to ancestors and gods. The moon cakes of the Mid-autumn festival and the special bread of Slava festival are the most representative foods. They are the same shape, are circular, but the volume difference: moon cake volume is small, the special bread volume is very big. They have different meanings: moon cakes symbolize reunion and reflect people's good wishes for family reunion. Slava's breads symbolize the gifts of nature and reflect the gratitude people feel for Jesus. These traditional delicacies constitute an important part of the festival customs; they not only enrich the festival culture of China and $\mathrm{BiH}$, but also more deeply understand the spiritual connotation of China and $\mathrm{BiH}$ through the unique food culture.

\subsubsection{Behavioral culture contrast}

Wine tasting, moon appreciating in Mid-autumn festival not only reflects the characteristics of folk activities, but also reflects the ancient people's interest in life. It is the profound agricultural culture of Chinese nation that cultivates a rich and colorful local customs. Handed down from generation to generation, continues to flourish has formed a strong traditional festival culture of Mid-autumn festival, bearing the Chinese nation's way of life.

In the Slava festival, red wine is poured on special bread and broken into small pieces in the form of a cross, which are shared and appreciated, make people grateful and sharing, which carry the essence of traditional Bosnian culture.

\subsubsection{Spiritual culture contrast}

The Mid-autumn festival is a time for family and friends to get together and share family life. The belief of family reunion and homesickness has always been the most internal and profound thing in Chinese national festival culture. The full moon reposes the infinite sentimentally attached to people's affection for the flesh and bone. Mid-autumn festival embodies the concept of blood is thicker than water. Moon appreciating is also the embodiment of the thought of "harmony between man and nature". The timing of the Mid-autumn festival reflects "conforming to nature", allowing people to arrange farming and leisure activities in accordance with the natural law and the characteristics of climate change, reflecting the distinctive characteristics of farming culture, people must follow the laws of nature and change, that is, harmony between human and the heaven, in order to obtain a good harvest and happiness.

The Slava festival embodies strong religious culture characteristics. The patron saint of every family is a character from a Bible story, which promotes the spirit of the Orthodox Church, the festival itself is rooted in religion, wine represents Jesus' blood, and the prayers in the celebration are thanks to Jesus, all of these are imbued with a deep and mysterious religious sense.

The Mid-autumn festival falls on 15th day of the 8th lunar month. All Chinese people celebrate it together on this day. The date of Slava festival varies from family to family, and the saints commemorated are different. This reflects a difference in values between the two countries: China is more collectivism, while $\mathrm{BiH}$ is more individualistic.

\subsection{Adhere to "Harmony in Diversity"}

On the basis of digging deeply into Chinese traditional culture, teachers need to fully comprehend "harmony in diversity ". In the process of cultural dissemination and thought collision, conflict and deviation are inevitable, and it is the embodiment of cultural hegemony to impose one's own views and opinions on others. In the process of Trans-cultural diffusion, countries and regions along "the Belt and Road Initiatives" have different religious beliefs and multiple value systems, and countries with strong cultures need to conduct self-examination of "cultural consciousness", on the basis of contradiction and collision, we seek common ground while shelving differences and achieve common development through exchanges, discussions and consultations.

Although the Mid-autumn festival and Slava festival are different in time, ceremony etc, in these two festivals, people are eager to live a life of reunion, peace and tranquility. Teachers should be good at finding "harmony" in the teaching process to improve teaching effectiveness.

\section{CONCLUSION}

International Chinese language teachers need to flexibly adjust the relationship between Chinese culture and the local culture of the country in which they teach, and constantly collide, communicate and dialogue in the environment of different cultural systems in China and local places, to form harmonious coexistence and positive interaction between cultural systems, to fully understand and respect local cultures, to become learners and researchers of heterogeneous cultures, to truly understand heterogeneous cultures, and to be more conducive to enhancing the influence of Chinese culture in 
heterogeneous cultures, we will work together to advance the civilization and progress of China and the world.

\section{ACKNOWLEDGMENT}

This research was financially supported by 2018 Shandong Province University Research Program (Humanities and Social Sciences) "Research on Chinese Language Communication in Bosnia and Herzegovina under the Belt and Road Initiatives" (Project Number: J18RB163).

\section{REFERENCES}

[1] Chun-li Yang, Chang-he Zhu. On the Differences between Chinese and British Cultures from the Perspective of Traditional Festivals,J. Journal of Changchun Normal University (humanities and Social Sciences Edition), 2007, 26(1):102

[2] Peng Zhao. The traditional Serbian Slava Festival has been added to the UNESCO list of non-heritages [J/OL].

Http://news.cri.cn/gb/42071/2014/11/28/5931s4783202. htm 28 Nov 2014

[3] Xiao-dong Dai. Theory of Intercultural Communication, Shanghai Foreign Language Education Press, 2011.

[4] Li-dan Chen, Yi-mo Yan. Communication Syllabus, Renmin University Press, 2007.

[5] Ling-ling Wang. How to construct Chinese Cultural Communication System under the Belt and Road Initiatives. People's Forum,J. 2016(28) 